\title{
Gender Inequality in Nepalese Agriculture: Issues Concerning Sustainability and Food Security
}

\section{Priya Tiwari ${ }^{1 *}$, Shuvam Shingh ${ }^{2}$}

\author{
${ }^{1}$ Naini Agricultural Institute, SHUATS, Prayagraj, 211007, UP, India \\ ${ }^{2}$ Warner College of Dairy Technology, SHUATS, Prayagraj, 211007, UP, India \\ *corresponding author: preeyatiwari18@gmail.com
}

\begin{abstract}
Despite of the advancement in technology and excessive use of chemical fertilizers for agricultural production, about 870 million people around the globe are hunger stricken due to various resource scarcities. There is a need to boost the agricultural productivity in order to feed the population which is growing in sky rocketing way. Food insecurity is a burning problem affecting nutrition, health and the betterment of population across the globe. Basically, food security depends on four pillars: availability, access, utilization and stability. Sustainable approaches in agricultural sector are of great importance to improve the food productivity and security along with mitigating nutrition problem around the world. In industrialized countries, less developed and developing countries, gaps in earnings by gender have long been evident. For the equivalent kind of work, women wages are found to be 60-75\% of men wages. The agricultural sector of Nepal contributes 28 percent to national GDP and this share tends to rise in the future years. At present the productivity of Nepal is sufficient to feed its population but there are a lot of problems related to gender inequality which eventually affects food and nutritional security. Several such aspects are discussed in this paper.
\end{abstract}

Keywords - Food Security, Gender inequality, Productivity, Sustainability.

\section{INTRODUCTION}

The mankind's dominion of planet earth came into existence by the revolutionary shift in the provision of food from hunting and gathering to agriculture (Helms, 2015). A frequent doubt voiced to the carrying capacity of the earth because of the rapidly growing population and limited resources has been a major point of concern of today's world (Smil, 1994).The livelihood of the majority of Nepalese population is dependent upon agriculture and livestock. As a major fraction of the country's population resides in the rural villages, agriculture and live stock has been established as a major source of income to the people. The agriculture sector of Nepal is found to mostly rely on the traditional farming and cultivation system. As per Central Bureau of Statistics (CBS, 2011), 83 percent of the population depends on agriculture and the same population resides in a rural area. The agricultural sector contributes 28 percent to national GDP (NRB, 2018); Chaudhary, 2018).

According to the International food policy research institute (IFPRI, 2011) the agriculture system must improve their

ISSN: $2456-1878$

https://dx.doi.org/10.22161/ijeab.52.19 sustainability and maintain its own viability by using techniques that allow for the continual reuse so as to ensure the food security. The concept of suitability is related to the potential for long term maintenance of wellbeing, which has ecological, economic, political and cultural dimensions (Smith and McDonald, 1998). The agriculture sector in Nepal is facing increasing obstacles from different sectors in order to meet the regular needs (CBS, 2011). The unsustainable environment in agriculture and food systems is the impact of gender inequality and lack of long-term maintenance and utilization of the resources. The word sustainable means pertaining to a system that maintain its own viability. Moreover, sustainability means keeping an effort going continuously or we can say the ability to last out and keep from falling.

For growth and maintenance activities, an individual requires energy and nutrients which is supplied by food. As per the United Nations committee on world food security, food security means that all people, at all-time have physical, social and economic access to sufficient, safe and nutritious food that meets food preferences and dietary needs for an 
active and healthy life.An average food energy availability of 2,900 kcal is considered satisfactory (Gilland, 2002). The current challenge to feed 7.6 billion people globally with limited and gradually decreasing cultivable land and food produce has ultimately posed the risk to food security. The global population is to be expected to rise to 9 billion by 2040 and if the growth rate remains the same, it will rise to 11 billion by 2100 (World Population Clock, 2015). So, the problem of food security is a burning issue for the developing countries like Nepal.

By now, the total crops produced in Nepal is enough to feed everyone residing in the nation. With the growing population and static productivity, the food security issue has evolved to a major concern. The cause of the lower food productivity and increasing issues of food security could be gender inequality and imbalance in the agriculture sector.

\section{AGRICULTURE SUSTAINABILITY AND FOOD SECURITY}

Agriculture is one of the most important practices developed by human race for their survival and proliferation on this planet. Because of agriculture, humans were able to shift their life style from Stone age and settled in colonies now we know as cities and villages. However, the growing population and limited resources lead to the invention and application of chemical fertilizers and pesticides which boosted the agricultural productivity initially (Arora, 2018). Due to the over use of chemical fertilizers and pesticides, the natural productivity of soil in the several regions of Nepal has decreased drastically which is posing a threat to food productivity, sustainability and eventually to the food security.Despite of the advancement in technology and excessive use of chemical fertilizers and pesticides for agricultural production, around 870 million people are hunger stricken due to various resource scarcities. There is a need to boost the agricultural productivity by $60 \%$ if we want to fulfill the need of 9 billion population in 2050(FAO,2012).Over use of chemical substances in agriculture sector has also led to severe environmental problems like pollution of soil, water and air, development of pesticide resistant organisms, loss of productivity of soil, and now is leading to serious threats to food security, biodiversity and human health (Aktar, 2009).

Sustainable approaches in agricultural sector are of great importance to improve the food productivity and security along with mitigating nutrition problem around the
world.Basically,food security depends on four pillars: availability, access, utilization and stability. Food and agricultural systems overlap not only in the area of food production, but also in the diverse areas like processing, transportation, marketing and many more (Capone et. al ,2014). Sustainability in Agriculture can be achieved by planning, utilizing and implementing the techniques of farming which would increase crop productivity so as to meet demands of growing population along with conserving and protecting environment and its natural sources (Arora, 2018). In order to achieve sustainability, upliftment of economic growth is necessary which has a direct link in achieving food security, improving nutrition and sustainable agriculture (SDGUSA, 2018).According to Chauhan et.al (2017),for ensuring food security and sustainability in agriculture, the traditional biological methods should be used by amalgamating it with recent innovations in biotechnology and bio-engineering, so as to utilize the genes of useful microbes and their metabolites as well as improving the industrial production of bio inoculants, respectively.

\section{CURRENT PRODUCTIVITY SCENARIO OF NEPAL}

Cereal crops have been a major element in addressing food security issues in Nepal. In recent years various fluctuation and different crop demand situation have been observed due to different reasons. The domestic production has not been enough to meet the rice demand in the recent years (MoAD/FAO/WFP, 2015). The five years import data of Nepal shows that the import value has inclined from NRs. 44.43 billion in 2009-10 to NRs. 127.51 billion in 2013-14 and it's still rising (Gairhe et. al, 2018). While we break the import statistics for the year in 2013-14 into parts, it is evident that of cereals from India was NRs. 35.12 billion of which rice share was NRs. 23.79 billion and the maize share was 7.43 billion (Kathmandu Post, 2015).

Timsina et al (2012) studied the status of food productivity and security and $r$ reported that Nepal has sufficient food to meet the national demand which is in contradiction to the import statistics. The terai region of Nepal had about 506247 $\mathrm{t}$ of food surplus in 2011, though the remaining two geographical regionsi.e Hills and Himalayas were facing the problem of food deficiency (Gairhe et. al 2018, Timsina et. al 2012). The Maize productivity in Nepal seemed to be growing by $2.4 \%$ between the year of 2001 and 2009(IFPRI, 2011; Gairhe et. al 2018). 
International Journal of Environment, Agriculture and Biotechnology, 5(2)

Mar-Apr, 2020 / Available: https://ijeab.com/

Table1: Total Cereal Production in Nepal in Different Years

\begin{tabular}{|c|c|c|c|}
\hline SN & Year & Value (MT) & Change in percent \\
\hline 1 & 2017 & 9758893 & 13.29 \\
\hline 2 & 2016 & 8614283 & -7.04 \\
\hline 3 & 2015 & 9266240 & -3.10 \\
\hline 4 & 2014 & 9562680 & 11.45 \\
\hline 5 & 2013 & 8580285 & -9.28 \\
\hline 6 & 2012 & 9457722 & 9.78 \\
\hline 7 & 2011 & 8615383 & 10.87 \\
\hline 8 & 2010 & 7770976 & -4.33 \\
\hline 9 & 2009 & 8122431 & 0.56 \\
\hline 10 & 2008 & 8077057 & 10.09 \\
\hline
\end{tabular}

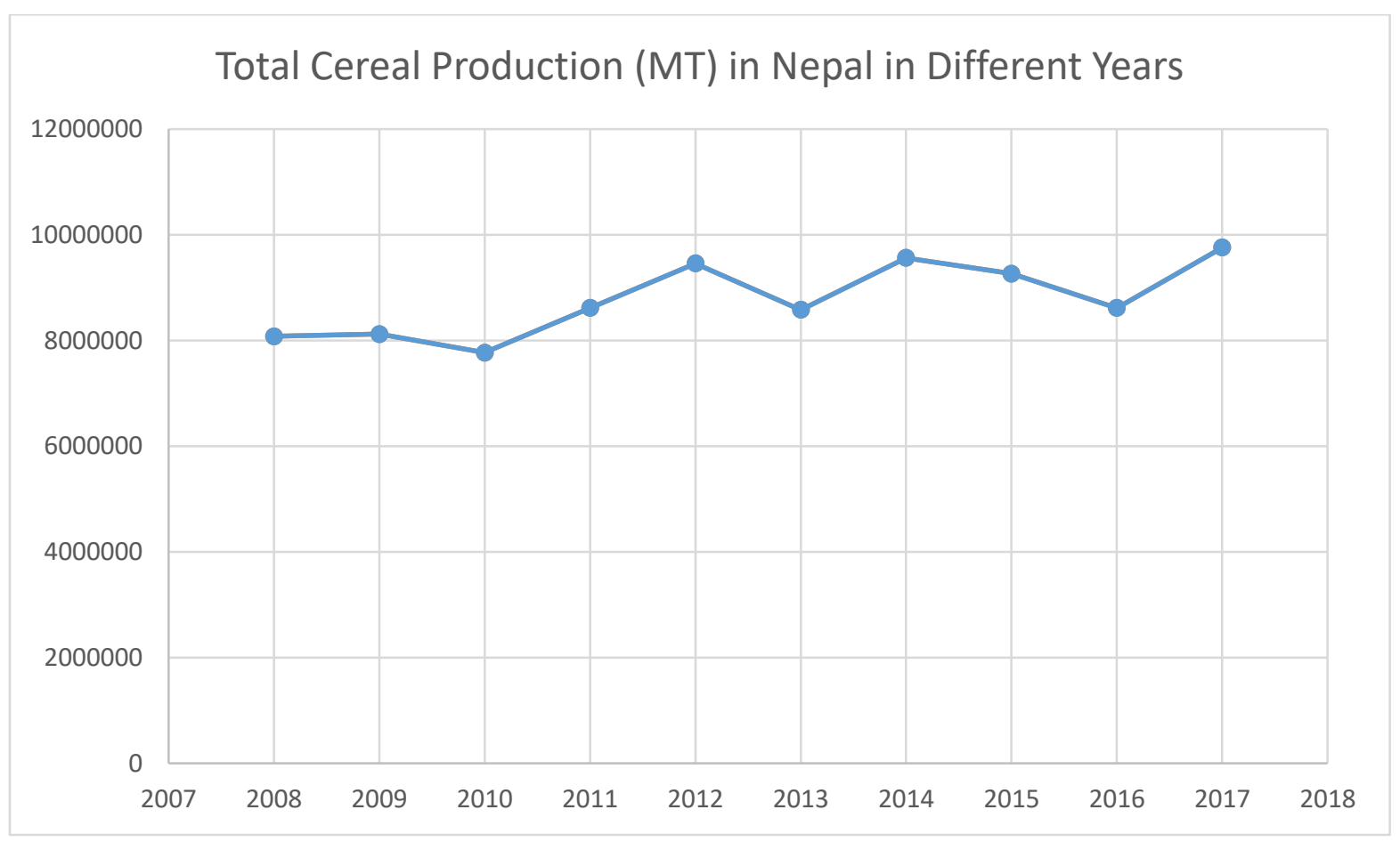

(World Data Atlas, 2017)

Shrestha et. al, (2011) studied the productivity scenario of pulse grain in Nepal and found that the share of Nepal in global pulse production was $0.4 \%$. The pulses like soybean is mainly grown in Nepal which occupies nearly about $10 \%$ of total cultivated land and ranks fourth in area after rice, wheat and maize (Shrestha et. al, 2011). Similarly, Grain legumes are grown in an area of 319,472 ha with production and productivity of 262,357 and $821 \mathrm{~kg} / \mathrm{ha}$, respectively (MoAC, 2009).

Area and production of fruits growing in Nepal is increasing as compared to previous year. According to the report published by the of Agricultural Development, Nepal, the total contribution of the various horticultural fruits i.e. orange, mango, banana and apple in AGDP is 1.4 percent, 3.88percent, 0.99 percent and 0.44 percent respectively. The 
total area covered for apple cultivation is 10926 ha and the production are $48946 \mathrm{MT}$ and productivity is $8.63 \mathrm{MT} / \mathrm{ha}$. Similarly, the fruits like banana and mango covers an area of 12503 ha and 40110 ha respectively. Likewise, the production of banana is 168484 MT and the production of mango is 328883 MT whereas banana and mango gives productivity of $15.23 \mathrm{MT} / \mathrm{ha}$ and $10.21 \mathrm{MT} / \mathrm{ha}$ respectively (Devkota, 2017, MoAD, 2013).

\section{GENDER ROLES AND WOMEN PRODUCTIVITY}

In industrialized countries, less developed and developing countries, gaps in earnings by gender have long been evident. For the equivalent kind of work, women wages are found to be $60-75 \%$ of men wages (Ali and Shields, 2010). The reason behind existence of this gap could be the women being less productive in certain works or the women being paid less than the marginal revenue product (Kumar and Hotchkiss, 1998). Nepalese industry absorbs only $6 \%$ of the labour work force (Cooke, 2000). A majority of women are dependent upon agriculture than i.e. 91\% of employed women are dependent upon agriculture than $64 \%$ of the males. (Ali and Shield, 2010). The high dependence of women on agriculture makes agricultural productivity a factor of concern. Nepal has an agriculture-based economy where women participate in almost all the activities of the agriculture as done by males. Gender based discrimination has got severe against women and their earnings and productivity. Discrimination against women can be noticed by simply looking at the wage rates. Coppin, (1998) also looked at wage differentials for agricultural laborers, and found that economic development and the adoption of new technology narrows the male/female wages. Thus, women productivity in Nepal is pretty low and is dependent upon multiple factors. For the improved agricultural productivity, moth male and women should be treated equally in all the aspects including wages and opportunities. Both male and female has equal roles for agriculture enhancement.

\section{STATUS OF WOMEN INVOLVED IN AGRICULTURE SECTOR OF NEPAL}

Agriculture is considered as the backbone of Nepalese economy. In Nepal, more than $68 \%$ of active population are involved in agriculture in which the maximum participation in agriculture activities are carried out by women, especially by residing in rural areas (USAID, 2017). Moreover, agriculture sector contributes to about $28 \%$ of national GDP in Nepal while the average GDP from agriculture of many countries is $10 \%$ (NRB,2018; USAID, 2017). Keeping in account to this context, the agriculture sector can further be enhanced by empowering women into agriculture.

Agriculture is a sector which is mainly comprised of production, processing and marketing. But in the context of Nepal, nearly about $80 \%$ of the women are involved in agricultural production sector as the labour forces than in processing and marketing dimensions (Sharma, 2018). The main reason why the women are lagging behind in other prospects of agriculture like industrial processing and marketing could be illiteracy and lack of ownership of agricultural resources such as land and agricultural equipment. (Sharma, 2018). Similarly, social structure and lack of exposure of scientifically advanced technologies can be other reason of poor status of women in Nepal.

\section{FOOD CRISIS AND GENDER INEQUALITY}

Food security is a complex issue, which deals with adequate food availability, economic and physical access to what is available. The food quality and its micro nutrient parameter is of equal importance. The unavailability of the quality food to the consumers lead to food crisis. The unavailability may be resulted due to lower production, higher production losses, higher population, and unequal participation of the population in agriculture. The role of women is pivotal in each of the cases. Gender equality is considered as one of the most essential components of sustainable agriculture, food security and poverty alleviation. Equitable access to more and better jobs in rural areas enable rural women to become effective economic actors and engines of growth; aid them in uplifting their standard of living by improving better quality of life (FAO,2010).

There's no debate about the importance of women for rural economic growth, poverty reduction and mitigating food crisis issues. Women are significant contributors to food availability as they are the major food producers.

Rural women have the ability to lift their households and communities out of poverty. But the persistent gender inequities are hampering women involvement which is in terms limiting their access to decent work. Hence, due to the unequal involvement of the population in agriculture all the aspects of it like productivity, processing and marketing gets affected which has given arises to a crucial situation of food crisis. 


\section{IMPACTS OF GENDER INEQUALITY IN AGRICULTURE SYSTEMS}

The participation of smallholder farmers is very critical for the agricultural development (Bill and Melinda foundation, 2008). The agricultural produce must be brought to the market for gaining the economic advantages. One of the constraints in guiding the agricultural commodities from farm to the market is Gender. However, ability for developing countries to perceive women as agents of food and nutritional security is influenced by a variety of factors. Women are the major agricultural producers and also are key agents of food and nutritional security (World Bank Group. 2015). But in the developing countries like Nepal they have less access to productive assets such as land and services such as finance and extension, relative to men. The ability of women to meaningfully participate in collective action as members of agricultural cooperative or water user associations is also guided by a number of factors in Nepal (Aguirre and Pietropaoli, 2008). Gender in a key element in agriculture because for better nutrition cannot be implemented and succeeded without taking into account of the social, economic and biological differences between men and women (Mtsor and Idisi, 2014). In spite of the substantial importance Nepal's extension systems do not sufficiently address the needs of female farmers or rural workers. So, from the above scenario it can be generalized that gender inequality results in less productivity which eventually causes less food to grow and distribute. Lesser productivity leads to lesser income and hence causes higher risk to poverty and food insecurity. Agriculture in Nepal if done properly with the adequate utilization of scientific tools and technologies along with the equal participation of both the men and female population could lead to poverty alleviation and improved life standards and quality of life. Hence, for the agricultural growth, gender disparities must be addressed and effectively reduced (Ogunlela and Mukhtur, 2009).

\section{METHODS OF ENSURING SUSTAINABILITY IN AGRICULTURE}

Simply, Sustainable agriculture means sustainable production system based on natural processes in which maximal but sustainable use of local resources is focused. Sustainable agriculture refers tothe form of agriculture which aims to meet the needs of present generation without jeopardizing the resource base of future generation. A sustainable system will possess the features like ecologically sound, economically viable, socially justifiable, humane and adaptable (Velten et.al,2015). Species diversity is essential to achieve self-regulation and resultant stability which is maintained through biological processes. Local resources must be used in a way that minimizes losses of nutrients, biomass, and energy and avoids pollution. More emphasis is given on the use of renewable resources. Economic viability must be there which means farmers can produce enough for self-sufficiency and/or income and gain sufficient returns to warrant the labour costs involved. Equal opportunity to participate in decision making, in the field and the society must be taken in consideration (FundsforNGOs,2016). The resources and the power must be distributed in such a way that basic needs of all the members should be met. The needs like rights to land use, adequate capital, technical assistance, market opportunities must be assured. The fundamental dignity of all human beings must be recognized, and relationship and institutions incorporate such human values as trust, honest, self-respect, co-operation and compassion. For flourishing agriculture, strong communities and vibrant culture is required. There must be the behavior of adaption by the rural communities in such way that they must be capable of adjusting to the constantly changing conditions for farming, viz. population growth, policies, market demand etc. This not only involves the development of new, appropriate technologies but also innovations in social and cultural terms. 


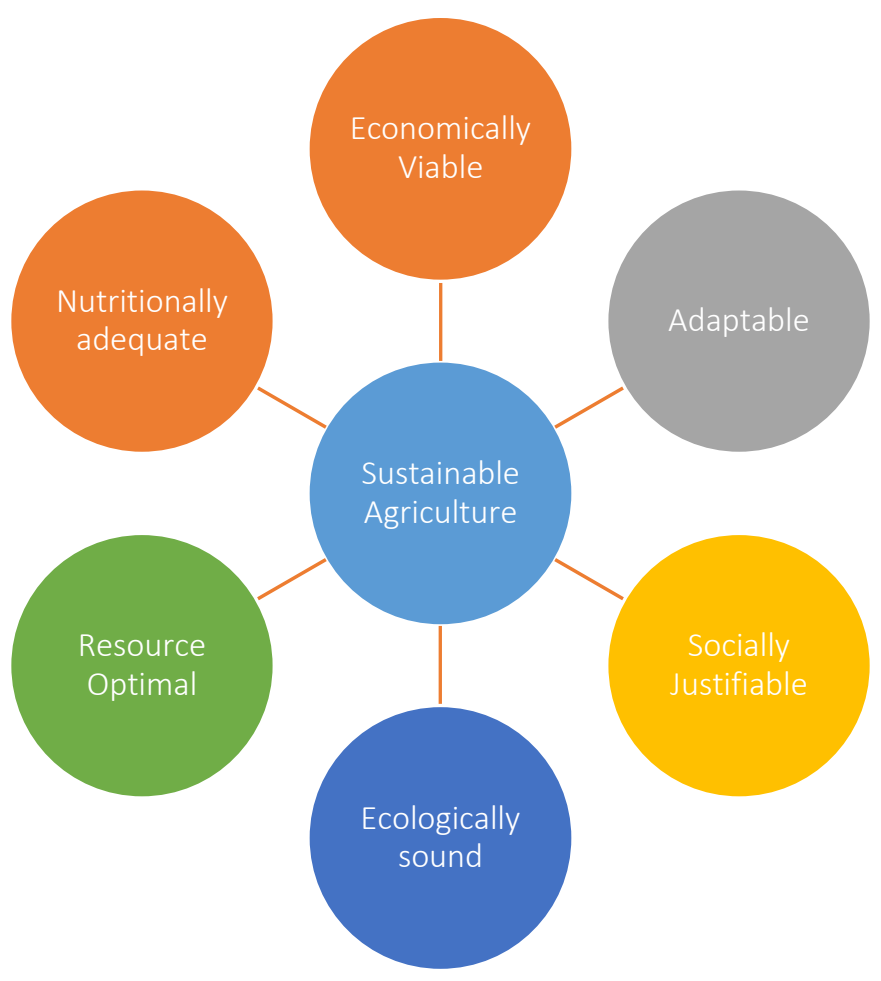

Fig.1: Characteristics of Sustainable Agriculture

Tey et.al (2012)

\section{CONCLUSION}

The changing food consumption patterns, population growth and reduced crop productivity has resulted in increasing food demand. The main concern of the food and agricultural sector is to provide enough quality food so as to meet the nutritional needs of a growing population in an environmentally, economically and socio-culturally sustainable way. Food production and its availability is very essential for mitigating hunger. However, food production in sufficient quantity only cannot guarantee food and nutritional security. In fact, food and nutrition security relies on four pillars: availability, access, utilization and stability. The current productivity of Nepal is enough for feeding its population. Ensuring food security is both the most basic of development issues and among the most important ones. Gender inequality is one of the leading causes of this problem and reducing those inequalities will be a critical part of the solution. The potential productivity of agriculture is reduced due to inequalities faced by women as producers and hence, overall food availability in countries also gets reduced. The agricultural sector of Nepal contributes 28 percent to national GDP and this share tends to rise in the future years. At present the productivity of Nepal is sufficient to feed its population but there are a lot of problems related to gender inequality which eventually affects food and nutritional security. Such issues should be addressed with the sustainable approaches and immediate action and care is required for the mitigation of the problems.

\section{REFERENCES}

[1] ADB, (2010), Overview of Gender Equality and Social Inclusion in Nepal. Retrieved from: adb.org/sites/default/files/institutional-document/32237/cganep-2010.pdf

[2] Aguirre D, Pietropaoli, I (2008). "Gender Equality, Development and Transitional Justice: The case of Nepal." International Journal of Transitional Justice. 2(3): 356-377. Doi: 10.1093/ijlj/ijno27.

[3] Aktar WM, Sengupta D and Chowdhury A, (2009), Impacts of pesticides used in agriculture: Their Benefit and Hazards, Interdisc Toxicol., Vol.2(1):1-12. DOI: 10.2478/v10102-0090001-7 
[4] AlyHY and Shields MP, 2010 MP, 2010 GENDER AND Agricultural productivity in a surplus labor, Traditional economy: Empirical Evidence from Nepal, The Journal of Developing Areas, Vol. 43, Number 2.

[5] Arora NK,(2018), Agricultural sustainability and food security,Environmental

1, Issue 3, pp 217-219

[6] Bill and Melinda foundation,2008, Gender Impact Strategy for agricultural development. Retrieved from:https://docs.gatesfoundation.org/documents/genderimpact-strategy.pdf

[7] Capone R, Bilali HE, Debs P,Cardone G, Driouech N, Food system sustainability and food security: Connecting the dots. Journal of Food Security, 2 (1), pp 13-22.DOI: 10.12691/jfs-2$1-2$

[8] CBS. (2011). National Population and Housing Census 2011. Kathmandu: National Planning Commission, Nepal.

[9] Chaudhary D. (2018), AGRICULTURAL POLICIES AND RURAL DEVELOPMENT IN NEPAL: AN OVERVIEW, Research Nepal Journal of Development Studies, Year 1st Issue $2^{\text {nd }}$, pp: $34-46$

[10] ChauhanA., RanjanA, JindalT, 2017, Biological control Agents for Sustainable Agriculture, Safe Water and Soil Health, Paradigms in Pollution Prevention, 71-83

[11] Cooke P. A. (2000). Changes in Intrahousehold Labor Allocation to Environmental Goods Collection. A case study from Rural Nepal, 1982 and 1997, International Food Policy Research Institute, 2000.

[12] Coppin A,(1998) "A comparison of male-female Earnings Differences across Two Caribbean Countries, "Journal of Developing Areas, 1998, Vol. 32, pp. 375-93

[13] Devkota S. (2017), Government Policies and periodic plan along with statistical data and pocket area of different commercial fruits grown in Nepal. Retrieved from: https://www.academia.edu/8977817/Status_of_fruit_in_Nepal? auto=download

[14] FAO, (2010), Gender Dimensions of agricultural and Rural employment: Differentiated pathways out of poverty-Status, trend and gap, Retrievedfrom:http://www.fao.org/3/i1638e/i1638e.pdf

[15] FundsforNGOs, (2016), How to ensure sustainability? Retrieved from: https://www2.fundsforngos.org/featured/howto-ensure-sustainability

[16] Gairhe S., Shrestha HK, Timsina K., (2018), Dynamics of Major Cereals Productivity in Nepal, Journal of Nepal Agricultural Research Council, Vol. 4: 60-71, ISSN: 23924535, DOI: 10.3126/jnarc. v4i1.19691

[17] Gilland B. (2002), "World population and food supply. Can food production keep pace with population growth in the next half-century?", Food Policy, Vol. 27, pp. 47-63.

[18] Helms M. (2015), Food sustainability, food security and the environment, British Food Journal Vol. 106 No. 5, 2004 pp. 380-387, DOI: 10.1108/00070700410531606
[19] IFPRI, (2011). A Review of Input and Output Policies for Cereals Production in Nepal. Discussion Paper 01114

[20] Kathmandu Post. (2015). Agro Product top import list. Accessed from http://kathmandupost.ekantipur.com/printedition/news/201511-27/agro-products-top-import-list.html

[21] Kumar SK and Hotchkiss D(1998), "Consequences of Deforestation for Women's Time Allocation, Agricultural Production, and Nutrition in Hills Area of Nepal, Research Report 69, International Food Policy Research Institute

[22] MoAC (2009) Statistical information on Nepalese Agriculture 2008/09. Agri-Business Promotion and Statistics Division, Ministry of Agriculture and Cooperatives, Kathmandu, Nepal

[23] MoAD/FAO/WFP. (2015.) Crop Situation Update: A joint assessment of 2014/15 winter crops. Published by Ministry of Agricultural Development, Food and Agriculture Organization and World Food Program, Kathmandu, Nepal.

[24] MoAD (2013). Statistical information on Nepalese Agriculture 2012/13. Agri-Business Promotion and Statistics Division, Ministry of Agriculture Development, Kathmandu, Nepal

[25] Mtsor YG and Idisi PD, 2014, Gender inequality and women participation in agricultural Development in Nigeria, Merit Research Journal of Education and Review (ISSN: 23502282), Vol. 2(11) pp. 296-301, Nov 2014.

[26] NRB. (2018). Nepal Rastriya Bank Monetary Policy 2018/19. Kathmandu: Nepal Rastriya Bank.

[27] Ogunlela YI and Mukhtar AA, 2009, Gender Issues in Agriculture and Rural Development in Nigeria: The Role of Women, Humanity and Social Science Journal, 4(1): 19-30, 2009.

[28] SDGUSA,(2018), SUSTAINABLE DEVELOPMENT REPORT OF THE UNITED STATES, Retrieved from: https://www.sdgusa.org/uploads/SDGreport2018.pdf

[29] Sharma A, (2018), Nepali women in farming. The Himalayan Times. Retrieved from: https://thehimalayantimes.com/opinion/nepali-women-infarming/

[30] Shrestha R., Neupane RK, and Adhikari NP (2011), Status and Future Prospects of Pulses in Nepal, Paper presented at Regional Workshop on Pulse Production held at Nepal Agricultural Research Council (NARC), Kathmandu, Nepal from 24-25 October 2011

[31] Smil V, (1994) how many people can the earth feed? Population and Development review,20, No.2

[32] Smith CS, McDonald GT, (1998), Assessing the sustainability of agriculture at the planning stage,Journal of environmental Management,52,15-37

[33] Tey YS, Li E, Bruwer J, Abdullah AM, Cummins J, Radam A, Ismail MM and Darham S,(2012), Refining the definition of sustainable agriculture: An inclusive perspective from Malaysian vegetable sector, Maejo Int. J. Sci. Technol., 6(03), 379-396, ISSN 1905-7873 
[34] Timsina KP, KP Shrestha and S Pandey. 2012. Factors affecting adoption of new modern varieties of Rice in eastern Tarai of Nepal. In: the proceeding of 4th Society of Agricultural Scientist-Nepal (SAS-N) conference held at Lalitpur 4-6 April, 2012. Published by Nepal Agricultural Research Council (NARC) and Society of Agricultural Scientists (SAS-N), Nepal, pp 48-54

[35] USAID,2017, Agriculture and Food security, Nepal, United States Agency for International Development, Retrievedfrom:https://www.usaid.gov/nepal/agriculture-andfood-security

[36] Velten S., Leventon, J., Jager, N., \& Newig, J. (2015). What Is

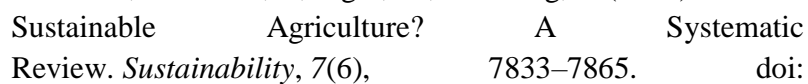
10.3390/su7067833

[37] World Bank Group, (2015), confronting drought in Africa's Drtlands, Cervidni, R. and Morris, M (Eds). Food and Agricultural Organization, International Food policy Research institute, Africa Development forum. The world Bank, Washington. DC

[38] World Data Atlas, 2017, Nepal-Cereal Production, Retrievedfrom:https://knoema.com/atlas/Nepal/Cerealproduction

[39] World Population Clock - Worldometers. (2015). Retrieved June 25, 2019, from Worldometers.info. website: https://www.worldometers.info/world-population/ 